\title{
A AUDIÊNCIA PÚBLICA NO PROCESSO ADMINISTRATIVO
}

EVANNA SOARES ${ }^{*}$

1. Introdução. - 2. Audiência Pública. - 2.1. O que é uma audiência pública? - 2.2. Audiência pública e democracia. - 2.3. Audiência pública e devido processo legal. - 2.4. Fundamento, natureza e qualificação. 2.5. Princípios - 2.6. Procedimento recomendado - 3. Audiência Pública no Processo Administrativo. - 3.1. Lei $n^{\circ}$ 9.784, de 1999. - 3.1.1. Considerações. - 3.1.2. Outros modos de participação popular na função administrativa. - 3.1.3. Natureza e fins da audiência pública. - 3.1.4. Pressupostos para realização. - 3.1.5. Participantes. - 3.1.6. Resultados. - 4. Outras Previsóes de Audiência Pública. - 4.1. No processo judicial. - 4.2. No processo legislativo. - 4.3. No Ministério Público. 4.4. Na Administração Pública. - 4.4.1. Audiência pública e meio ambiente. - 4.4.2. Na Lei $n^{\circ}$ 8.666, de 1993 (licitaçôes e contratos administrativos). - 4.4.3. Na Lei $n^{\circ} 8.987$, de 1995 (concessão e permissão de seniços públicos). - 4.4.4. Na Lei $n^{\circ}$ 9.427, de 1996 (concessões de energia elétrica). - 4.4.5. Na Lei $1^{\circ}$ 9.478, de 1997 (agências reguladoras). - 4.4.6. Na Lei n' 10.257, de 2001 (Estatuto da Cidade). - 5. Considerações Finais. - referências.

\section{Resumo}

A audiência pública é uma das formas de participação e de controle popular da Administração Pública no Estado Social e Democrático de Direito. Ela propicia ao particular a troca de informações com o administrador, bem assim o exercício da cidadania e o respeito ao princípio do devido processo legal em sentido substantivo. Seus principais traços são a oralidade e o debate efetivo sobre matéria relevante, comportando sua realização sempre que estiverem em jogo direitos coletivos. A legislação brasileira prevê a convocação de audiência pública para realização da

* Procuradora Regional do Ministério Público do Trabalho. Chefe da Procuradoria Regional do Trabalho da 22a Região. Pós-graduada em Direito Processual. Doutoranda em Ciências Jurídicas e Sociais. 
função administrativa, dentro do processo administrativo, por qualquer dos Poderes da União. inclusive nos casos específicos que versam sobre meio ambiente, licitações e contratos administrativos concessão e permissão de serviços públicos. serviços de telecomunicações e agências reguladoras. Constitui. ainda. instrumento de realização da missão institucional do Ministério Público e subsídio para o processo legislativo e para o processo judicial nas ações de controle concentrado da constitucionalidade das normas.

\section{Introdução}

O principal instituto da teoria do direito administrativo tem sido o ato administrativo. Todos os estudos e cuidados sempre se voltaram para o ato. como se ele se bastasse e existisse sozinho. Ultimamente, com o advento do Estado Social e Democrático de Direito. essas atenções passaram a se voltar para o processo administrativo'. compreendendo-se. finalmente. que é através do processo que a função administrativa se realiza. e não do ato isolado, que. na verdade, é o resultado da atividade desenvolvida por intermédio daquele.

O Estado Democrático de Direito relaciona-se intimamente com o processo administrativo. que the serve de instrumento para o maior controle da atividade da Administração Pública. bem assim para viabilizar a participação popular na expedição do referido ato, de sorte que o princípio democrático consegue se consumar através do controle e da participação - os quais constituem as mais relevantes finalidades do processo administrativo $\mathrm{O}^{2}$.

Salienta Maria Sylvia Zanella Di Pietro ${ }^{3}$ que o princípio da participação popular na gestão da Administração Pública pontifica na Constituição da República do Brasil de 1988. como exemplo. nos arts. 10. 187, 194, 194, VII. 198. III, 204, II, 206. VI e $216, \$ 1^{\circ}$. bem assim os instrumentos de controle, como se vê, entre outros, no art. $5^{\circ}$, XXXIII. LXXI e LXXIII. e no art. $74, \S 2^{\circ}$. Essa participação do cidadão se implementa de várias formas, tais a presença de ouvidores nos órgãos públicos, criação de "disque-denúncia", audiências públicas e consultas públicas.

A audiência pública - um desses mecanismos de participação e controle popular e que constitui o objeto deste estudo - tem recebido da doutrina enfoques sob diversas óticas. Odete Medauar ${ }^{4}$ e Celso Antônio Bandeira de Mello a apreciam quando explicam a instrução do processo administrativo, isto é, as "atividades de averiguar e comprovar os dados necessários à tomada de decisão" 5 . Sérgio Ferraz e Adilson Abreu Dallari ${ }^{6}$ vêem a audiência pública sob o prisma da publicidade. como veículo para "obter maior publicidade e participação" dos cidadãos, direta-

1 MELlo. Rafael Munhoz de. Processo Administrativo. Devido Processo Legal e a Lei $n^{\circ}$ 9.784/99. p. 83-85.

2 MELLO. Rafael Munhoz de. Processo Administrativo... p. 85.

3 Dircito Administrativo. p. 517-519.

+ Direino Administrativo Moderno, p. 216.

5 Curso de Dircive Administrativo. p. 448-449.

6 Processo Administration p. 142-144. 
mente ou através de entidades representativas, no processo de tomada de decisão. Essa audiência é examinada por Vera C. C. M. Scarpinella Bueno ${ }^{7}$. por sua vez, preponderantemente, sob o ângulo da simplificação e da eficiência do processo administrativo, democratizando e legitimando as decisões da Administração Pública.

Mostra-se interessante, assim. estudar a audiência pública no processo administrativo, particularmente a sua inserção na Lei do Processo Administrativo Federal (Lei $\mathrm{n}^{\circ}$ 9.784, de 1999), bem como a previsão de sua realização para o desempenho de outras funções estatais. perscrutando sua natureza, características e finalidades.

\section{Audiência pública}

\subsection{O que é uma audiência pública?}

Audiência pública é um instrumento que leva a uma decisão política ou legal con legitimidade e transparência. Cuida-se de uma instância no processo de tomada da decisão administrativa ou legislativa, através da qual a autoridade competente abre espaço para que todas as pessoas que possam sofrer os reflexos dessa decisão tenham oportunidade de se manifestar antes do desfecho do processo. É através dela que o responsável pela decisão tem acesso, simultaneamente e em condições de igualdade, às mais variadas opiniões sobre a matéria debatida. em contato direto com os interessados. Tais opiniões não vinculam a decisão, visto que têm caráter consultivo, e a autoridade, embora não esteja obrigada a segui-las, deve analisá-las segundo seus critérios, acolhendo-as ou rejeitando-as ${ }^{8}$.

Na Administração Pública a audiência pública - instrumento de conscientização comunitária - funciona como veículo para a legítima participação dos particulares nos temas de interesse público. Então, de um lado, tem-se uma metodologia de esclarecimento de determinadas questões através da presença dos interessados, e, de outro, uma Administração que, anteriormente, se mantinha distante dos assuntos cotidianos dos cidadãos, e, agora, se preocupa com o interesse comum, a exemplo do serviço público de eletricidade".

Agustín Gordillo ${ }^{10}$ ressalta que a extensão do princípio da audiência individual ao princípio da audiência pública tem suas raízes no direito anglo-saxão, fundamentando-se no princípio de justiça natural - o mesmo que nutre a garantia de defesa nos casos particulares e o devido processo legal festejado nos Estados Unidos da América e na própria Argentina. Esse princípio, na prática, se traduz em que, antes da edição de normas administrativas ou mesmo legislativas de caráter geral, ou de decisões de grande impacto na comunidade, o público deve ser escutado.

7 As leis de procedimento administrativo..., p. 283-287.

* PODER CIUDADANO. Manejando conflitos y mejorando la transparencia a traiés de la participación ciudadana: El caso del Pluente La Serna en Argenina. Disponível na Internet em http://ww'w.poderciudadano.org.ar/prog05E.htm. Acessado em 09.07.2002.

y ARGENTINA. Secretaría de Energía del Ministerio de Economia. Ente Nacional Regulador de la Eletricidad. Las audiências públicas. Disponivel na Internet em http://ww'w.enre.gov.ar/ web/web.nst/Files/97.07.pdf\$FILE/97p07.pdf. Acessado em 09.07.2002.

10 Tratado de Derecho Administrativo, tomo II, p. XI-2. 
O princípio da audiência pública. no direito argentino. onde é fartamente prestigiado, tem sede constitucional, constando, por exemplo. do art. 63 da Constituição da Cidade Autônoma de Buenos Aires ${ }^{11}$.

"ARTíCUlo 63. - La Legislanura, el Poder Ejecutivo o las Comunas pueden convocar a audiencia pública para debatir asuntos de interés general de la ciudad o zonal, la que debe realizarse con la presencia inexcusable de los funcionarios competentes. La convocatoria es obligatoria cuando la iniciativa cuente con la firma del medio por ciento del electorado de la Ciudad o zona en cuestión. También es obligatoria antes del tratamiento legislativo de provectos de normas de edificación, planeamiento urbano, emplazamientos industriales o comerciales, o ante modificaciones de uso o dominio de bienes públicos".

As audiências públicas previstas nesse dispositivo têm interessante detalhamento na Lei $n^{\circ}$ 6. ditada pela Legislatura da Cidade de Buenos Aires em 05.3.1998 ${ }^{12}$. revelando seu objeto e finalidade nos cinco primeiros artigos, que merecem transcrição, considerado seu caráter geral:

"Artículo $1^{\circ}$ - La presente Ley regula el Instituto de Audiencia Pública. La Audiencia Pública constituye una instancia de participación en el proceso de toma de decisión administrativa o legislativa en el cual la autoridad responsable de la misma habilita un espacio institucional para que todos aquellos que puedan verse afectado o tengan un interés particular expresen su opinión respecto de ella. El objetivo de esta instancia es que la autoridad responsable de tomar la decisión acceda a las distintas opiniones sobre el tema en forma simultánea y en pie de igualdad a través del contacto directo con los interesados.

Art. $2^{\circ}$ - Las opiniones recogidas durante la Audiencia Pública son de carácter consultivo y no vinculante. Luego de finalizada la Audiencia. la autoridad responsable de la decisión debe explicitar, en los fundamentos del acto administrativo o normativo que se sancione, de qué manera ha tomado en cuenta las opiniones de la ciudadanía y, en su caso, las razones por las cuales las desestima.

Art. $3^{\circ}$ - La omisión de la convocatoria a la Audiencia Pública, cuando ésta sea un imperativo legal, o su no realización por causa imputable al órgano convocante es causal de nulidad del acto que se produzca en consecuencia. quedando abierta la actuación judicial.

Art. $4^{\circ}-$ El incumplimiento del procedimiento estipulado en la presente ley podrá ser causal de anulabilidad del acto, por vía administrativa o judicial.

11 Disponivel na Internet em http:/www.legislatura.gov.ar/llegisla/constcba/htm. Acessado em 09.07.2002.

12 Ley $n^{\circ} 6$ Audiencia Publica de la Ciudad de Buenos Aires Argentina. Disponível na Internet em http://www aaba.org.ar/bi040006.htm. Acessado em 09.07.2002. O Regulamento de Audiências Públicas pode ser consultado em http:/www.gba.gov.ar/mosp/fiduciario/reglamento.htm. 
Art. $5^{\circ}$ - Las Audiencias Públicas son temáticas, de requisitoria ciudadana o para designaciones y acuerdos".

A doutrina brasileira, na expoente voz de Diogo Figueiredo MOREIRA NETO ${ }^{13}$, define audiência pública como "um instituto de participação administrativa aberta a indivíduos e a grupos sociais determinados, visando à legitimação administrativa, formalmente disciplinada em lei, pela qual se exerce o direito de expor tendências, preferências e opções que possam conduzir o Poder Público a uma decisão de maior aceitação conceitual".

Mas, além de servir ao exercício da função administrativa, a audiência pública no Brasil se presta, também, para subsidiar o desempenho da função legislativa, conforme art. $58, \S 2^{\circ}$. II, da Constituição da República de 1988, da função judiciária (art. $9^{\circ}, \S 1^{\circ}$, da Lei $n^{\circ} 9.868 / 1999$ ) e da missão institucional do Ministério Público (art. 27, parágrafo único, IV, da Lei $n^{\circ} 8.625 / 1993$ ).

\subsection{Audiência pública e democracia}

A realização de audiências públicas está intimamente ligada às práticas democráticas.

Ela representa. juntamente com a consulta popular, a democratização das relações do Estado para com o cidadão, aqui considerado não mais o administrado conforme expressão criticada por CASSESSE, em desuso porque traduz a idéia de sujeição - mas sim um "parceiro do administrador público". concretizando a participação popular externa na Administração Pública ${ }^{14}$.

O exercício do poder pelo povo e para o povo é assegurado pelo princípio democrático, que gera, além dos direitos de elaboração legislativa, os direitos participativos, que "fundamentam pretensões à satisfação dos fins sociais, culturais e ecológicos da igualdade de gozo das liberdades privadas e dos direitos de participação política" 15 , de sorte que o próprio conceito de democracia se assenta no princípio participativo, o qual integra o conceito de Democracia Social.

Consulta popular (ou enquête) e audiência pública constituem técnicas de execução desse processo participativo verificado na Administração Pública ${ }^{16}$.

O Estado Democrático de Direito é caracterizado pela participação direta, referindo-se à terceira fase de evolução da Administração Pública, em que o particular, individual e pessoalmente, influencia na gestão, no controle e nas decisões do Estado $^{17}$, como decorrência do princípio democrático. A democracia participativa, assim, é consequiencia da insuficiência da democracia representativa reinante no final

13 Direito da Participação Política. Legislativa - Administrativa - Judicial, p. 129.

14 SOARES. Fabiana de Menezes. Direito Administrativo de Participação..., p. 169.

15 SOARES, Fabiana de Menezes. Direito Administratio de Participação.... p. 65-69.

16 SOARES. Fabiana de Menezes. Direito Administratio de Participação..., p. 165-166.

17 DI PIETRO. Maria Sylvia Zanella. Participą̧ão Popular na Administração Pública, p. 32-33. 
do Século XX e decorre da exigência da presença direta dos particulares na tomada de decisôes coletivas ${ }^{18}$, através das audiências públicas, por exemplo.

\subsection{Audiência pública e devido processo legal}

Todas as vezes que a Administração Pública resolve limitar o exercício de direitos individuais, deve assegurar ao interessado o direito de ser previamente ouvido, relacionando-se essa garantia com o direito de defesa. o princípio do contraditório e com o devido processo lega ${ }^{14}$.

Esse princípio clássico da audiência prévia se projeta para a audiência pública. como regra de validade quase universal. expressando a garantia constitucional do devido processo legal em sentido substantivo ${ }^{20}$. visto que ela deve se realizar antes de ser adotada uma providência de caráter geral. tal a edição de normas jurídicas administrativas ou mesmo legislativas e a aprovação de projetos de grande impacto ambiental.

Com efeito. além de efetivar a garantia de receber informações da Administração e de ser ouvido por ela. a audiência pública também possibilita o pleno exercício da defesa e do contraditório pelo cidadão, individualmente ou através de associações ${ }^{21}$.

\subsection{Fundamento, natureza e qualificação}

A audiência pública tem importância material porque é ela que dá a sustentação fática à decisão adotada ${ }^{22}$. Quem mais se beneficia de seus efeitos são os próprios particulares, considerada a prática de uma administração mais justa, mais razoável, mais transparente. decorrente do consenso da opinião pública e da democratização do poder.

O fundamento prático da realização da audiência pública consiste do interesse público em produzirem-se atos legítimos. do interesse dos particulares em apresentar argumentos e provas anteriormente à decisão, e. pelo menos em tese, também do interesse do administrador em reduzir os riscos de erros de fato ou de direito em suas decisões, para que possam produzir bons resultados. Tem a ver com o antigo "princípio jurídico audi alteram pars: es la necesidad política. jurídica y práctica de escuchar al público antes de adoptar una decisión. cuando ella consiste en una medida de carácter general, un proyecto que afecta al usuario o a la comunidad, al medio ambiente: o es una contratación pública de importancia, etc." ${ }^{23}$.

A audiência pública tem dupla natureza pública. como observa Agustín GORDILLO $^{2+}$ : a primeira representada pela publicidade e transparência próprias do

is MODESTO. Paulo. Participação Popular na Administração Priblica. Mecanismos de Operacionalização. p. 2.

19 DI PIETRO. Maria Sylvia Zanella. Participação Popular na Administraçăo Páblica. p. 33-34.

20 GORDILLO. Agustín. Tratado de Derecho Administrativo. tomo II, p. XI-2.

2 SOARES. Fabiana de Menezes. Direito Administrativo de Participaçūo.... p. 164.

22 GORDILLO. Agussín. Tratado de Derecho..., p. X1-5.

33 GORDILLO. Agustín. Tratado de Derecho.... p. XI-7.

24 Tratado de Derecho..., p. XI-7-8. 
mecanismo. em que pontuam a oralidade, imediação, assistência, registros e publicações dos atos; a segunda, pela própria participação processual e a abertura a todos os segmentos sociais.

O que qualifica a audiência pública, nesse contexto, é a participação oral e efetiva do público no procedimento ordenado, como parte no sentido jurídico, e não meramente como espectador ${ }^{25}$.

É indispensável. assim, para que se realize a audiência pública, propriamente dita, a efetiva participação do público. Não se caracterizará como tal a sessão que, embora aberta ao público, o comportamento dos presentes seja passivo, silencioso, contemplativo. Nesse caso, será apenas uma audiência. Outrossim, se não se observar um formal e previamente estabelecido procedimento, também não se estará diante de uma audiência pública. mas de mera reuniāo popular, com livre troca de opiniões entre o administrador e os particulares acerca de determinado tema ${ }^{26}$.

\subsection{Princípios}

Considerando que a audiência pública serve à função administrativa, inclusive quando destinada ao controle e regulação dos serviços de utilidade pública privatizados, salienta Agustín Gordillo ${ }^{27}$ que ela deve se realizar à moda do processo judicial oral e seguir os princípios jurídicos de caráter geral. tais o devido processo legal, publicidade, oralidade, simplicidade das formas, contraditório, participação do público, instrução, impulso oficial, economia processual e, via de regra, gratuidade.

\subsection{Procedimento recomendado}

O jurista argentino adverte para a necessidade de serem observados esses princípios, tendo-se o cuidado para não exagerar na regulamentação, de sorte a deixar margem para a criatividade dos responsáveis pela realização da audiência pública, visando aos bons e efetivos resultados. Recomenda, então, as linhas gerais do procedimento da audiência pública ${ }^{28}$. consistentes de: pré-estabelecimento da ordem ou roteiro da audiência pelo seu dirigente ou dirigentes, contendo a relação, sequiência e tempo das pessoas que usarão da palavra, réplicas, apartes, etc.; providências para a ampla divulgação ao público da convocação da audiência; realização, quando necessário, de uma pré-audiência visando à ordenação ou simplificação do temário. coleta de informaçōes, ou, ainda, para tentar um acordo de partes. desde que não afete $o$ interesse público, aplicando-se, nessa hipótese, o princípio da economia processual: instrução através de depoimentos e interrogatórios dos interessados e testemunhas, recebimento de documentos, laudos periciais. etc.: documentação dos atos mediante taquigrafia, gravação em áudio e vídeo, lavratura da ata da audiência; e recebimento e registro de alegações orais.

25 GORDILLO. Agustín. Tratado de Derecho.... tomo II. p. XI-8.

26 GORDILLO, Agustín. Tratado de Derecho.... tomo II. p. XI-9.

27 Tratado de Derecho..., tomo II. p. XI-10.

28 Tratado de Derecho..., tomo II. p. XI-10/19. 


\subsection{Lei $n^{\circ} 9.784$, de 1999}

\subsubsection{Considerações}

O processo administrativo no Brasil vinha sendo tratado casuisticamente pela doutrina e pela jurisprudência à falta de lei específica sobre o tema. somente implementado, no âmbito da Administração Pública Federal, em 20/01/1999. com a edição da Lei $n^{\circ}$ 9.784. A demora legislativa nacional mostra-se maior ainda, se se considerar, entre outros países, que Áustria (1925). Espanha (1958), Alemanha (1978), Uruguai (1966) e Argentina (1972), há muito tempo dispõem de lei da espécie, como ressalta Rafael Munhoz de Mello ${ }^{29}$.

Essa lei vem impulsionando a evolução do processo administrativo e traz, como novidade institucionalizada com o fim de implementar a função administrativa pelos órgãos e entidades da Administração Direta e Indireta do Poder Executivo, bem assim pelos órgãos do Poder Judiciário e do Poder Legislativo, a previsão de participação popular direta na formação dos atos administrativos de grande relevância, nos casos de interesse público, encontrando-se, dentre as formas de participação, a audiência pública.

$\mathrm{O}$ art. 32 da lei sob comento estabelece que, "antes da tomada de decisão, a juízo da autoridade, diante da relevância da questão, poderá ser realizada audiência pública para debates sobre a matéria do processo".

A audiência pública está inserida no capítulo "da instrução" do processo administrativo, ocasião em que se constrói a motivação das decisões administrativas e se efetua a ponderação dos interesses envolvidos.

\subsubsection{Outros modos de participação popular na função administrativa}

A Lei $n^{\circ} 9.784 / 1999$, no art. $31, \S \S 1^{\circ}$ e $2^{\circ}$, prevê, expressamente, outro meio instrutório do processo administrativo, qual seja, a consulta pública, deliberada quando a matéria envolver assunto de interesse geral e destinada a colher manifestação de terceiros, desde que não haja prejuízo para a parte interessada, antes da decisão do pedido.

Convém. de logo, distinguir audiência pública de consulta pública. Embora ambas constituam formas de participação popular na gestão e controle da Administração Pública, não se confundem.

A audiência pública propicia o "debate público e pessoal por pessoas físicas ou representantes da sociedade civil", considerado "o interesse público de ver debatido tema cuja relevância ultrapassa as raias do processo administrativo e alcança a própria coletividade" ${ }^{30}$. Cuida-se, no fundo. de modalidade de consulta pública, com a

29 Processo Administratio.... p. 83.

30 CARvalho FILHO. José dos Santos. Processo Administrativo Federal. p. 185-186. 
particularidade de se materializar através de "debates orais em sessão previamente designada para esse fïm “31. A oralidade. portanto, é seu traço marcante.

A consulta pública. por seu turno. tem a ver com o interesse da Administração Pública em "compulsar a opinião pública através da manifestação firmada através de peças formais, devidamente escritas, a serem juntadas no processo administrativo" 32 .

Além da consulta e audiência públicas, a Lei $n^{\circ} 9.784 / 1999$, no art. 33. faculta aos órgãos e entidades administrativas, nas matérias relevantes, a adoção de outros meios de participação popular, a exemplo de reuniões, convocações e troca de correspondências. Trata-se de norma de natureza residual, como evidencia José dos Santos Carvalho Filho ${ }^{33}$, cujo objetivo é franquear todas as formas possíveis de participação pública, coibindo o autoritarismo e viabilizando o exercício da cidadania.

\subsubsection{Natureza e fins da audiência pública}

A natureza da audiência pública prevista na Lei $n^{\circ} 9.784 / 1999$ não discrepa daquela apontada por Agustín Gordillo ${ }^{3+}$, e se resume na efetiva participação popular no processo de tomada da decisão administrativa.

Segundo o art. 32 da referida lei, que. como dito, dispõe sobre a audiência pública como mecanismo de instrução do processo administrativo, a fïnalidade de sua realização é o amplo debate acerca de questão relevante. afeta ao interesse geral da coletividade, via de regra identificada pela presença de interesses metaindividuais, difusos ou coletivos, de sorte a não atingir direitos da população sem sua prévia oitiva. Objetiva-se, assim, "permitir debates sobre a matéria" 35 .

A prática das audiências públicas, pelos aspectos positivos da sua instituição no processo administrativo, notadamente quanto ao controle da função administrativa, merece ser generalizada no direito positivo, segundo a opinião de Alice Gonzalez Borges ${ }^{36}$.

\subsubsection{Pressupostos para realização}

O requisito para realização da audiência pública é a relènancia da questão. Essa relevância é traduzida pela presença do "interesse coletivo de reconhecida importância" " ${ }^{77}$. Com efeito, "não basta que haja interesse geral: é importante que a decisão no processo possa realmente influir na esfera de interesse de outras pessoas na

3 CARVALHO FILHO. José dos Santos. Processo Administrativo Federal. p. 186.

32 CARVAlho FILHO. José dos Santos. Processo Administrativo Federal, p. 186.

33 Processo Administrativo Federal, p. 188.

$3+\mathrm{V}$. nota $\mathrm{n}^{\circ} 24$.

35 DI PIETRO, Maria Sylvia Zanella. Direito administratiro, p. 518.

36 Processo Administratio e Controle, p. 179.

37 CARVALHO FILHO. José dos Santos. Processo Administrativo Federal. p. 187. 
coletividade. Por outro lado, se o interesse se configurar como relevante. estará ultrapassando os limites do processo administrativo e do próprio interesse da parte ${ }^{\cdots 38}$. Exemplos clássicos de relevância encontram-se nas questões que envolvem os interesses dos consumidores e o meio ambiente.

Compete à autoridade responsável pela decisão identificar a relevância da questão e convocar a audiência pública antes do desfecho do processo administrativo. Essa providência não é meramente formal, apenas para cumprir, aparentemente, a etapa procedimental. É necessário sejam dadas todas as condições para que a audiência se realize plenamente, com a participação ativa e efetiva da população, e que o seu conteúdo seja considerado quando da decisão, sob pena de invalidade ${ }^{34}$. É verdade que a audiência pública prevista no art.32 da Lei $n^{\circ} 9.784 / 1999$ não tem caráter compulsório, visto que sua realização fica a critério da autoridade administrativa, uma vez detectada a relevância da matéria. Mas, se entendida necessária, deve ser cumprida efetivamente, prezando-se pela oralidade e debates que caracterizam o mecanismo de participação popular e controle.

Infere-se, outrossim, diante da existência de pressupostos para convocação da audiência pública. que ela não pode ser realizada para outra finalidade que não a prevista em lei, isto é, debater relevante matéria do processo. Se a intenção do administrador for outra, como, meramente, colher opiniões especializadas ou transmitir informações aos particulares, há-de lançar mão de outra modalidade de evento, tais as reuniões, consultas, seminários, congressos, etc., e não da audiência pública.

\subsubsection{Participantes}

A participação na audiência pública pode se dar de forma direta ou indireta. No primeiro caso, tem-se o próprio particular. pessoalmente, em nome próprio, a comparecer e expor sua opinião, debater e aduzir razões sobre a matéria relevante e de interesse geral. No segundo, quem participa é organização ou associação legalmente reconhecida, tais as " associações, fundações, sociedades civis, enfim, toda e qualquer entidade representativa, cuja participação possa atender aos interesses daqueles que se fazem por ela representar" 40 .

Denominam-se partes, em sentido amplo, os participantes da audiência pública, segundo a lição de Agustín Gordillo ${ }^{+1}$. admitindo-se todos aqueles que tenham interesse legítimo ou direito subjetivo, bem assim interesse coletivo, inclusive pessoas públicas supra-nacionais, internacionais ou estrangeiras, bem como as privadas, conforme o caso. Enfim, "quaisquer pessoas, ONGs, partidos políticos, etc.", que "discutam previamente as decisões a serem tomadas pela Administração" 4?.

38 CARVAlHO FILHO. José dos Santos. Processo Administrativo Federal. p. 187.

3) MELLO. Rafael Munhoz de. Processo Administration... p. 88.

40 CARVAlho fILHO. José dos Santos. Processo Administrativo Federal. p. 189.

4 Tratado de Derecho Administrativo. tomo II. p. XI-15.

42 SUNDFEL.D, Carlos Ari. Processo e procedimento administrativo no Brasil, p. 35. 


\subsubsection{Resultados}

No mundo jurídico, como na vida, nada se faz sem um sentido, sem a preocupação com um resultado almejado. A audiência pública, como meio de participação dos particulares na Administração Pública, deve ter, por imperativo da Lei $n^{\circ}$ $9.784 / 1999$, art. 34 , seus resultados apresentados com a indicação do procedimento adotado.

Tem, assim, o responsável pela realização da audiência pública, duas obrigações ${ }^{43}$, nessa fase: primeiramente, dar forma ao resultado através de relatório do que se desenvolveu na audiência, especialmente opiniões e debates necessários à formulação de uma conclusão, ainda que incompleta. Em segundo lugar, indicar, além do resultado, o procedimento adotado como forma de participação popular no processo para debate da matéria, isto é, a menção do procedimento levado a efeito, para que se possa efetuar o cotejo entre o modo de participação e o meio escolhido pela Administração.

\section{Outras previsões de audiência pública}

\subsection{No processo judicial}

A Lei $\mathrm{n}^{\circ}$ 9.868, de 10.11.1999, que "dispõe sobre o processo e julgamento da ação direta de inconstitucionalidade e da ação declaratória de constitucionalidade perante o Supremo Tribunal Federal", no art. $9^{\circ}, \S 1^{\circ}$, estabelece que "em caso de necessidade de esclarecimento de matéria ou circunstância de fato ou de notória insuficiência das informações existentes nos autos, poderá o relator requisitar informaçōes adicionais, designar perito ou comissão de peritos para que emita parecer sobre a questão, ou fixar data para, em audiência pública, ouvir depoimentos de pessoas com experiência e autoridade na matéria".

O controle abstrato das normas é feito em processo objetivo, quer dizer, sem partes ou sujeitos e destina-se, exclusivamente, à defesa da Constituição ${ }^{44}$. O legislador introduziu no procedimento desse processo, inovadoramente, a audiência pública. para que o relator, se entender necessário, possa ouvir depoimentos de pessoas com experiência e autoridade na matéria.

Aqui, a audiência pública não visa a dar publicidade ao processo - mesmo porque ele já é público - nem se presta para subsidiar uma decisão administrativa. O STF. quando em exercício de sua função administrativa, realizará audiência pública tal qual todos os órgãos da Administração Pública, conforme art. $1^{\circ}, \S 1^{\circ}$, da Lei $n^{\circ} 9.784 / 1999$. No uso de sua competência constitucional e no exercício da função jurisdicional de dizer, em controle concentrado, sobre a constitucionalidade

4.3 CARVAlho FILHO, José dos Santos. Processo Administrativo Federal, p. 189.

14 MARTINS, Ives Gandra da Silva e MENDES, Gilmar Ferreira. Controle Concentrado de..., p. 85-88. 
ou inconstitucionalidade das normas, o Excelso Pretório, através do relator do processo, poderá se valer da audiência pública para instruir o feito e forrar a decisão judicial a ser proferida.

A audiência pública, nesse contexto, constitui um dos importantes instrumentos "para aferição dos fatos e prognoses legislativos no âmbito do controle abstrato das normas", como ressaltam Ives Gandra Martins e Gilmar Ferreira Mendes. Isso traduz maior abertura procedimental e uma grande modernização do processo constitucional brasileiro, ao tempo em que fornece ao STF "instrumentos adequados para uma aferição mais precisa dos fatos e prognoses estabelecidos ou pressupostos pelo legislador" 45 .

Essa abertura procedimental dá ao Tribunal mais elementos técnicos para que possa apreciar a constitucionalidade do ato impugnado e propicia, amplamente, a participação de terceiros "interessados" na matéria, através da audiência pública.

A participação de pessoas e entidades permite a transformação de um processo dito subjetivo em um processo objetivo de controle da constitucionalidade, visto que interessa a todos, tal como se vê na praxe americana do "amicus curiae brief", servindo como "excelente instrumento de informação para a Corte Suprema e de integração dos diferentes grupos nos processos judiciais relevantes para a sociedade ${ }^{+6}$.

As audiências públicas funcionam, assim, como um ampliado instrumento de informação aos Ministros responsáveis pela dicção da constitucionalidade, de sorte a viabilizar os elementos probatórios adequados para o racional, técnico e consciente exame da matéria, fatos e prognoses legislativas, afastando as decisões meramente intuitivas e evitando que o "voluntarismo do legislador" seja substituído "pelo voluntarismo do juiz" ${ }^{47}$.

A realização de audiência pública no processo concentrado de controle da constitucionalidade das normas, em determinados casos. permitirá a aferição judicial dos efeitos práticos do ato inquinado, bem assim de sua eventual retirada do mundo jurídico.

\subsection{No processo legislativo}

O Poder Legislativo, tal qual o Poder Judiciário, quando meramente no desempenho da função administrativa, realizará audiências públicas nos moldes da Lei $n^{\circ}$ 9.784/1999, como prevê seu art. $1^{\circ}, \S 1^{\circ}$.

O processo legislativo, porém, tem na realização de audiências públicas com entidades da sociedade civil uma incumbência irrecusável.

45. Controle Concentrado de Constitucionalidade. p. 158-159.

to MARTINS, Ives Gandra e MENDES. Gilmar Ferreira. Controle Concentrado de Constitucionalidade. p. 181-182.

47 MARTINS. Ives Gandra e MENDES, Gilmar Ferreira. Controle Concentrado..., p. 183. 
Com efeito, a realização dessa audiência decorre de comando constitucional (art. $58, \$ 2^{\circ}$, II, da Carta de 1988), cumprindo sua implementação às comissões do Congresso Nacional e de suas Casas.

Ressalta Celso Ribeiro Bastos que o referido dispositivo constitucional tem o "sentido de integrar representantes e representados através de audiências". Acresce que "as audiências públicas com entidades da sociedade civil são realizadas quando questões de interesse social ou mesmo de segmentos específicos da sociedade forem suscitadas". E arremata: "tais audiências, portanto, configuram espaços voltados ao debate coletivo" 48 .

O Regimento Interno do Senado Federal, no art. 90, II, estabelece como uma das competências das Comissões a realização de "audiências públicas com entidades da sociedade civil (Const. art. $58, \S 2^{\circ}$, II)".

O Regimento Interno da Câmara dos Deputados, por sua vez, trata da audiência pública com mais detalhes, nos arts. 255 a 258 :

“Art. 255. Cada Comissão poderá realizar reunião de audiência pública com entidade da sociedade civil para instruir matéria legislativa em trâmite, bem como para tratar de assuntos de interesse público relevante, atinentes à sua área de atuação, mediante proposta de qualquer membro ou a pedido de entidade interessada.

Art. 256. Aprovada a reunião de audiência pública, a Comissão selecionará, para serem ouvidas, as autoridades, as pessoas interessadas e os especialistas ligados às entidades participantes, cabendo ao Presidente da Comissão expedir os convites.

$\S 1^{\circ} \mathrm{Na}$ hipótese de haver defensores e opositores relativamente à matéria objeto de exame, a Comissão procederá de forma que possibilite a audiência das diversas correntes de opinião.

$\S 2^{\circ} \mathrm{O}$ convidado deverá limitar-se ao tema ou questão em debate e disporá, para tanto, de vinte minutos, prorrogáveis a juízo da Comissão, não podendo ser aparteado.

$\S 3^{\circ}$ Caso o expositor se desvie do assunto, ou perturbe a ordem dos trabalhos, o Presidente da Comissão poderá adverti-lo, cassar-lhe a palavra ou determinar a sua retirada do recinto.

$\S 4^{\circ} \mathrm{A}$ parte convidada poderá valer-se de assessores credenciados, se para tal fim tiver obtido o consentimento do Presidente da Comissão.

$\S 5^{\circ}$ Os Deputados inscritos para interpelar o expositor poderão fazê-lo estritamente sobre o assunto da exposição, pelo prazo de três minutos, tendo o interpelado igual tempo para responder, facultadas a réplica e a tréplica, pelo mesmo prazo, vedado ao orador interpelar qualquer dos presentes.

Art. 257. Não poderão ser convidados a depor em reunião de audiência pública os membros de representação diplomática estrangeira.

Art. 258. Da reunião de audiência pública lavrar-se-á ata, arquivando-se, no 
âmbito da Comissão, os pronunciamentos escritos e documentos que os acompanharem.

Parágrafo único. Será admitido, a qualquer tempo, o traslado de peças ou fornecimento de cópias aos interessados".

Observa-se, assim, que o papel da audiência pública, aqui, é instruir o processo legislativo e subsidiar os parlamentares para o adequado exercício de suas funções institucionais.

Como é cediço, a prática da realização de audiências públicas se estende pelas Casas Legislativas estaduais e municipais, regendo-se os procedimentos pelos Regimentos Internos respectivos, conservando-se, porém, a finalidade, qual seja, a integração entre representantes e representados, propiciando o debate coletivo em torno de matérias de interesse geral.

\subsection{No Ministério Público}

O Ministério Público, "instituição permanente, essencial à função jurisdicional Uo Estado, incumbindo-lhe a defesa da ordem jurídica, do regime democrático e dos interesses sociais e indisponíveis" - como define a Constituição da República no art. 127, "caput" - a exemplo dos órgãos dos Poderes Executivo, Legislativo e Judiciário, quando no desempenho meramente da função administrativa, deve realizar audiência pública em conformidade com a Lei ${ }^{\circ}$ 9.784/1999.

Para o exercício de suas funções institucionais previstas no art. 129 da Carta Constitucional, conta, porém, com previsão específica de audiência pública na legislação orgânica.

A Lei $n^{\circ}$ 8.625, de 12.02.1993 (Lei Orgânica Nacional do Ministério Público, que dispõe sobre normas gerais para a organização do Ministério Público, entre outras providências), quando trata das funções gerais da Instituição, no art. 27. parágrafo único, IV, determina ao "Parquet". entre outras medidas necessárias à defesa dos direitos assegurados nas Constituições Federal e Estadual, que promova audiências públicas:

"Art. 27. Cabe ao Ministério Público exercer a defesa dos direitos assegurados nas Constituições Federal e Estadual, sempre que se cuidar de garantir-lhe o respeito:

I - pelos poderes estaduais ou municipais;

II - pelos órgãos da Administração Pública Estadual ou Municipal, direta ou indireta;

III - pelos concessionários e permissionários de serviço público estadual ou municipal;

IV - por entidades que exerçam outra função delegada do Estado ou do Município ou executem serviço de relevância pública.

Parágrafo único. No exercício das atribuições a que se refere este artigo, cabe ao Ministério Público, entre outras providências:

I - receber notícias de irregularidades, petições ou reclamações de qualquer 
natureza, promover as apurações cabíveis que lhes sejam próprias e dar-lhes as soluções adequadas;

II — zelar pela celeridade e racionalização dos procedimentos administrativos;

III - dar andamento, no prazo de trinta dias, às notícias de irregularidades, petições ou reclamações referidas no inciso I:

IV - promover audiências públicas e emitir relatórios, anual ou especiais, e recomendações dirigidas aos órgãos e entidades mencionadas no caput deste artigo, requisitando ao destinatário sua divulgação adequada e imediata, assim como resposta por escrito".

Hugo Nigro Mazzilli dedica um capítulo da obra $O$ Inquérito Civil às audiências públicas cometidas ao Ministério Público, considerada a sua relevância para o desempenho da missão institucional do "Parquet". Observa que se trata de um mecanismo novo na legislação orgânica da Instituição, importado de outros países onde servia para que os cidadãos participassem da gestão da coisa pública, envolvendo-os no próprio processo de decisão do Governo, revestindo, assim, a decisão, de maior publicidade e legitimidade ${ }^{49}$.

As audiências públicas têm a ver, portanto, “com a passagem de uma democracia representativa para uma democracia participativa" 50 .

O objeto da audiência pública institucional cometida ao Ministério Público, porém, não é o mesmo quando realizada pela Administração Pública como elemento da instrução do processo administrativo ou para desempenhar sua função administrativa. Também não tem natureza político-governamental. Nesse caso, segundo Hugo Mazzilli, ela é

" apenas um mecanismo pelo qual o cidadão e as entidades civis (as entidades chamadas não governamentais) podem colaborar com o Ministério Público no exercício de suas finalidades institucionais, e, mais especialmente, participar de sua tarefa constitucional consistente no zelo do interesse público e na defesa de interesses metaindividuais (como o efetivo respeito dos Poderes Públicos aos direitos assegurados na Constituição, o adequado funcionamento dos serviços de relevância pública, o respeito ao patrimônio público, ao meio ambiente, aos direitos dos consumidores, aos direitos das crianças e adolescentes, à produção e programação das emissoras de rádio e televisão, etc.)" 51 .

A realização de audiências públicas apresenta-se para o Ministério Público não como uma submissão da Instituição ao controle popular, mas, sim, como palco para coleta de subsídios para sua atuação na defesa dos relevantes interesses públicos que

49 MAZZILLI, Hugo Nigro. O Inquérito Civil. p. 325.

50 Cf. Daniel Alberto SABSAY e Pedro TARAK, citados por Mazzilli. ob. cit.. p. 326.

51 MAZZILLI, Hugo Nigro. O Inquérito Civil. p. 326-327. 
Ihe são confrados. de sorte a guiar as providências por um juizo mais aproximado da realidade e das necessidades da coletividade. legitimando, ainda mais, suas ações.

Não impõe a lei ao Ministério Público o dever de realizar audiência pública, que é colocada como um dos instrumentos para o desempenho de sua missão institucional. e que deve ser utilizado diante de problemas mais complexos, com cuidado, porém. de um lado, para não ficar esquecido, sem aplicação, e, de outro, para não banalizá-lo.

O juízo da conveniência e da necessidade de convocar a audiência pública seja pelos órgãos do Ministério Público dos Estados, seja do Ministério Público da União, por seus diversos ramos, incumbidos, igualmente, da defesa dos mesmos direitos e interesses, no âmbito das Justiças Especializadas perante as quais atuam (v. Lei Complementar $\mathrm{n}^{\circ}$ 75, de 20.5.1993) - compete ao membro (Promotor ou Procurador), que será responsável, dentro do procedimento adequado - geralmente o inquérito civil - também. pela expedição do ato convocatório e do regulamento da audiência de conformidade com os objetivos perseguidos.

Inspirado no modelo administrativo argentino. Hugo Mazzilli sugere um roteiro básico para a audiência pública a cargo do Ministério Público, consistente da publicação do aviso de realização da audiência contendo a finalidade, resumo do regulamento, data e local do ato: expedição de ofícios. convites e convocações; coordenação dos trabalhos. inclusive a elaboração da pauta das atividades, registro das presenças. tomada de depoimentos. recebimento de documentos e lavratura da ata; e elaboração da conclusão, com divulgação da decisão tomada ${ }^{52}$.

A realização de audiências públicas é, portanto. de significativa utilidade para o desempenho da missão institucional do Ministério Público, em especial para as atuações de grande relevância. tais as voltadas para defesa do meio ambiente, inclusive o meio ambiente do trabalho. e outras que digam respeito a interesses coletivos e difusos.

\subsection{Na Administração Pública}

\subsubsection{Audiência pública e meio ambiente}

Conforme Édis Milaré Ş3 $^{3}$ em matéria ambiental, audiência pública constitui um "procedimento de consulta à sociedade, ou a grupos sociais interessados em determinado problema ambiental ou potencialmente afetado por um projeto, a respeito de seus interesses específicos e da qualidade ambiental por eles preconizada". Sua realização deve seguir requisitos regulamentares pertinentes a "forma de convocação. condições e prazos para informação prévia sobre o assunto a ser debatido, inscrições para participação. ordem dos debates, aproveitamento das opiniões expedidas pelos participantes". Nesse contexto, arremata o referido autor que "a audiência pública faz parte dos procedimentos do processo de avaliação de impacto am-

52 O Inquérito Civil. p. 328-333.

5.3 Direito do Ambiente. p. 650. 
biental em diversos países (Canadá, Estados Unidos, França. Holanda, etc.). como canal de participação da comunidade nas decisões de âmbito local".

O Estado e a sociedade exercem controle sobre a qualidade dos estudos de impacto ambiental, basicamente de três formas: o controle comunitário. feito pelo público, onde se insere. com destaque, a audiência pública; o controle administrativo. realizado pela própria agência ou órgão ambiental; e o controle judicial. via ações protetivas do ambiente $e^{54}$.

$\mathrm{O}$ instrumento normativo pioneiro na previsão de audiências públicas para realização da função administrativa tendente à proteção do meio ambiente no Brasil foi a Resolução $\mathrm{n}^{\circ} 001$. de 23.01.1986. publicada no DOU de 17.01.1986, editada pelo Conselho Nacional do Meio Ambiente - CONAMA - órgão consultivo e deliberativo integrante do Sistema Nacional do Meio Ambiente. cuja finalidade é "assessorar, estudar e propor ao Conselho de Governo as diretrizes de políticas governamentais para o meio ambiente e os recursos naturais e deliberar, no âmbito de sua competência, sobre normas e padrões compatíveis com o meio ambiente ecologicamente equilibrado e essencial à sadia qualidade de vida" 55 .

No uso da sua função normalizadora o CONAMA editou a Resolução ${ }^{\circ}$ $006 / 1986$, que, no art. $11, \S 1^{056}$, determina a promoção de "realização de audiência pública para informação sobre o projeto e seus impactos ambientais e discussão do RIMA" (relatório de impacto ambiental), sempre que julgar necessário, pelo órgão estadual competente. IBAMA ou pelo Município, que determinar a execução do estudo de impacto ambiental e apresentação do RIMA, contemplando prazo para recebimento de comentários a serem feitos por órgãos públicos e demais interessados.

A audiência pública mereceu detalhamento na Resolução CONAMA $n^{\circ} 009$. de 03.12.1987, publicada no DJU somente em 05.7.1990 ${ }^{57}$. a qual disciplina a finalidade, iniciativa, prazos e procedimento da audiência pública em matéria ambiental.

Nesse contexto, a finalidade da audiência pública é "expor aos interessados o conteúdo do produto em análise e do seu referido RIMA, dirimindo dúvidas e recolhendo dos presentes críticas e sugestões a respeito" (art. $1^{\circ}$ da Resolução $n^{0}$ 009).

Nos termos do art. $2^{\circ}$. "caput". dessa Resolução, a audiência pública deverá ocorrer quando for julgada necessária pelo órgão competente para outorga da licença ambiental, ou mediante solicitação de entidade civil, do Ministério Público ou de 50 ou mais cidadãos.

54 MILARÉ, Édis. Direito do Ambiente, p. 310-311.

55 Art. $6^{\circ}$, II, da Lei $n^{\circ}$ 6.938. de 31.8.1981. que dispōe sobre a Política Nacional do Meio Ambiente. entre outras providências.

56 Disponivel na Internet em http://www.mma.gov.br/port/conama/res/res $86 / \mathrm{res} 0186 . \mathrm{html}$. Acesso em 09.7.2002.

57 Disponivel na Internet em http://www.mma.gov.br/port/conama/res/res87/res0987.html. Acesso em 09.7.2002. 
Para abrir a oportunidade de manifestação da entidade civil, do Ministério Público ou dos cidadãos. o órgão competente de meio ambiente deve veicular edital na imprensa local abrindo prazo de 45 dias, pelo menos, em que poderá ser postulada a realização da audiência pública (art. $2^{\circ}, \S 1^{\circ}$, dessa Resolução).

$\mathrm{O}$ art. $2^{\circ}, \S 2^{\circ}$, da Resolução em comento, fulmina, expressamente, de nulidade. a licença concedida pelo Órgão Estadual sem atendimento da solicitação de audiência pública.

Celso FIORILLO ${ }^{58}$ explica que, "se a iniciativa partir do órgão competente para a concessão da licença", a audiência pública "se dará antes de iniciada a execução do EIA" (estudo de impacto ambiental), "ou, depois de recebido o RIMA, durante o prazo estabelecido pelo art. 10 da Resolução CONAMA n 001/86", isto é, por ocasião da manifestação conclusiva sobre o RIMA.

Poderá haver mais de uma audiência pública sobre o mesmo projeto e respectivo RIMA, dependendo da localização geográfica dos solicitantes e da complexidade do tema, a qual deve ocorrer em local acessível e será dirigida pelo representante do órgão responsável pelo licenciamento, que, depois de expor, objetivamente, o projeto e seu RIMA, abrirá as discussões com os interessados presentes, lavrando-se, ao final dos trabalhos. ata sucinta, à qual serão anexados os documentos escritos e assinados entregues no ato, servindo, tudo, à análise e parecer final do licenciador quanto à aprovação, ou não, do projeto (arts. $2^{\circ}, 3^{\circ}, 4^{\circ}$ e $5^{\circ}$, da mencionada Resolução $n^{\circ}$ 009/1987). Cumpre ressaltar que o resultado da audiência pública, cuja natureza é consultiva ${ }^{59}$. e, embora não vincule a decisão sobre o pedido de licença ambiental, "não poderá ser posto de lado pelo órgão licenciador", que deverá considerar nos motivos dessa decisão, acolhendo ou rejeitando os argumentos e documentos nela produzidos, sob pena de invalidação judicial ou administrativa ${ }^{60}$.

A audiência pública se acha reafirmada no art. $10, \mathrm{~V}$, da Resolução $\mathrm{n}^{\circ} 237$, de 19.12.1997 $7^{61}$, como etapa do procedimento de licenciamento ambiental, "quando couber, de acordo com a regulamentação pertinente".

A realização de audiência pública não só para análise do RIMA, como também do EIA que lhe antecede. decorre da própria Constituição da República, que, no art. $225, \S 1^{\circ}$. IV. determina que se lhe dê publicidade, e é nesse momento que "o órgão público presta informações ao público e o público passa informações à Administração Pública" ${ }^{62}$, concretizando o princípio da informação que norteia e legitima o procedimento necessário ao licenciamento ambiental, através da participação popular ${ }^{63}$.

58 Manual de Direito Ambiental e Legislação Aplicável, p. 133.

59 ANTUNES, Paulo de Bessa. Direito Ambiental, p. 222.

60 MACHADO. Paulo Affonso Leme. Direito Ambiental Brasileiro, p. 191.

61 Disponivel na Internet em http://www.mma.gov.br/port/conama/res/res97/res23797.html. Acesso em 09.7.2002.

62 MACHADO, Paulo Affonso Leme. Direito Ambiental Brasileiro. p. 187.

63 FIORILLO. Celso Antonio Pacheco. Manual de Direito Ambiental é Legislação Aplicável. p. 233 
A audiência pública ambiental, nesse contexto, funciona como o "instrumento de garantia mais importante para o efetivo exercício" do princípio da publicidade e do princípio da participação pública ou comunitária ${ }^{6+}$ consagrados entre os fundamentais pela Constituição da República.

Não se pode esquecer, porém, a advertência de Paulo de Bessa Antunes ${ }^{65}$ : nada obstante o objetivo legal da audiência pública seja "assegurar o cumprimento dos princípios democráticos que informam o Direito Ambiental", com a troca de informações entre os particulares e a Administração Pública, "a pouca tradição democrática de nossa sociedade faz com que a audiência pública seja, de longe, o mais criticado dos institutos jurídicos posto à defesa do meio ambiente".

\subsubsection{Na Lei $n^{\circ} 8.666$, de 1993 (licitaçōes e contratos administrativos)}

Essa lei, no art. 39, "caput", determina seja o processo licitatório, nos casos em que se estime para a licitação ou para um conjunto de licitações simultâneas ou sucessivas valor superior a $\mathrm{R} \$ 150.000 .000,00$, iniciado com audiência pública providenciada pela autoridade responsável com antecedência mínima de quinze dias úteis da data prevista para a publicação do edital, observada a divulgação com antecedência não inferior a dez dias úteis da data da realização, pelas mesmas vias da publicidade da licitação. devendo ser prestadas informações e dados acesso e direito de se manifestar a todos os interessados.

A razão de ser dessa audiência pública tem a ver com a ampla publicidade e o "controle da legalidade e da conveniência das licitações e contratações administrativas", notadamente as de maior vulto ${ }^{66}$.

Inclusive os aspectos discricionários da atividade administrativa constituirão seu objeto, e os participantes (interessados) serão os cidadãos, considerada a legitimação ativa da ação popular, devendo todas as ocorrências verificadas na audiência pública constar da respectiva ata e juntada aos autos da licitação ${ }^{67}$.

A Lei $n^{\circ} 8.666 / 1993$, nesse art. 39, diz que a audiência pública será realizada obrigatoriamente. Interessa, então, perquirir as conseqüências de eventual descumprimento do comando legal, mas, nesse particular, a doutrina não é uniforme.

Lúcia Valle Figueiredo, citada por Gustavo Henrique Justino de Oliveira ${ }^{68}$, nada obstante admita a não vinculação do resultado da audiência pública à decisão proferida na licitação, sustenta a invalidade do processo no caso de não realização daquele ato.

Marçal Justen Filho ${ }^{69}$ atenua essa conclusão e, partindo da premissa que audiência pública não é veículo para realização de direitos subjetivos, mas sim para

64 MILARÉ, Edis. Direito do Ambiente, p. 309 e 99.

65 Direito Ambiental, p. 221.

66 JUSTEN FILHO, Marçal. Comentários à Lei de Licitaçōes e Contratos Administrativos, p. 394.

67 JUSTEN FILHO, Marçal. Comentários à Lei de Licitaçôes... p. 394.

68 As audiências públicas.... p. 164.

69 Comentários à Lei de Licitações.... p. 394-395. 
proteção objetiva do interesse público, somente admite a nulidade do processo licitatório detectada posteriormente à contratação quando a ausência ou invalidade da audiência pública infringir o próprio interesse público, devendo ser ponderada a conveniência de decretar-se a nulidade e indenizar-se o particular - pagando, assim, duas vezes. o mesmo serviço ou obra, e valorizando a audiência pública como se fosse um fim em si mesma - ou, então, reservar o decreto anulatório somente para os casos de má-fé do particular ou agressão ao princípio da economicidade. Em suma, para o referido autor a ausência da audiência pública. apesar da dicção legal, não leva. por si só, à nulidade do procedimento.

\subsubsection{Na Lei $n^{\circ}$ 8.987, de 1995 (concessão e permissão de seniços públicos)}

A Lei $n^{\circ}$ 8.987. de 13.02.1995. trata do "regime de concessão e permissão da prestação de serviços públicos”, a que se refere o art. 175 da Constituição da República. Embora não contemple. expressamente, a audiência pública, contém vários dispositivos que demandam a sua realização. tais o art. $3^{\circ}$ (para implementação da "cooperação dos usuários") ${ }^{70}$. $\mathrm{o}$ art. $7^{\circ}$. I e II (para que os usuários possam exercer o direito de receber o serviço adequado e as informações para defesa de interesses individuais e coletivos do poder concedente ou da concessionária), o art. 21 (para colocar à disposição dos interessados "os estudos, investigações, levantamentos, projetos, obras e despesas ou investimentos já efetuados, vinculados à concessão, de utilidade para a licitação, realizados pelo poder concedente ou com a sua autorização"), o art. 29. XII (para "estimular a formação de associações de usuários para defesa de interesses relativos ao serviço") e no art. 30. parágrafo único (para escolha dos representantes dos usuários na comissão encarregada de fiscalizar o serviço periodicamente).

\subsubsection{Na Lei $n^{\circ} 9.427$, de 1996 (concessões de energia elétrica)}

A Lei $n^{\circ}$ 9.427. de 26.12.1996, instituiu a Agência Nacional de Energia Elétrica (ANEEL) - autarquia federal - e disciplina o regime das concessões de serviços públicos de energia elétrica, entre outras providências.

Seu art. $4^{\circ}, \S 3^{\circ}$. dispõe que "o processo decisório que implicar afetação de direitos dos agentes econômicos do setor elétrico ou dos consumidores, mediante iniciativa de projeto de lei ou, quando possível, por via administrativa, será precedido de audiência pública convocada pela ANEEL".

Aqui a audiência pública é prevista para ressalva do devido processo legal o que deve ocorrer não somente nos processos disciplinares, como se poderia imaginar, mas em "todas as hipóteses em que haja limitações ao exercício dos direitos individuais" $" 71$.

70) OLIVEIRA, Gustavo Henrique Justino de. As aucí̂ncias públicas e o processo administrativo brasileiro, p 165.

71 DI PIETRO. Maria Sylvia Zanella. Participação Popular na Administração Pública, p. 34. 
Observa-se que são duas as situações previstas no referido dispositivo. No primeiro caso, a ANEEL deve (obrigatoriamente, em qualquer hipótese) convocar a audiência pública diante da iniciativa de projetos de lei que afetem direitos dos agentes econômicos do setor elétrico ou dos consumidores. No outro, "quando possível" (isto é, quando as condições de tempo, lugar, conveniência, etc., permitirem), a realização da audiência pública precederá às decisões administrativas que tenham as mesmas consequiências junto aos agentes econômicos ou consumidores de energia elétrica.

\subsubsection{Na Lei $n^{\circ} 9.478$, de 1997 (agências reguladoras)}

A Lei $\mathrm{n}^{\circ} 9.478$, de 06.8.1997. por sua vez, "dispõe sobre a política energética nacional, as atividades relativas ao monopólio do petróleo" e. entre providências, instituiu o Conselho Nacional de Política Energética e a Agência Nacional do Petróleo - esta submetida a regime autárquico especial com a "finalidade de promover a regulação, a contratação e a fiscalização das atividades econômicas integrantes da indústria do petróleo" (art. $8^{\circ}$, "caput").

Do art. 19 dessa lei consta que "as iniciativas de projetos de lei ou de alteração de normas administrativas que impliquem afetação de direito dos agentes econômicos ou de consumidores e usuários de bens e serviços da indústria do petróleo serão precedidas de audiência pública convocada e dirigida pela ANP".

Esse dispositivo, comum às leis que regem as agências reguladoras ${ }^{72}$, obriga a realização de audiência pública nas hipóteses mencionadas, e constitui exemplo da "presença do princípio da participação do administrado na Administração Pública, dentro de um objetivo maior de descentralizar as formas de sua atuação e de ampliar os instrumentos de controle" ${ }^{73}$. revelando, ainda, o cuidado com o devido processo legal.

Observa Paulo Affonso Leme Machado ${ }^{74}$ que a lei sob comento valorizou, com pioneirismo, como dever da ANP, a "audiência pública como procedimento para debater projetos de lei ou discutir a alteração de normas administrativas, com repercussão nos direitos dos agentes econômicos. consumidores e usuários", a qual deve ser precedida de publicidade e possibilitar a efetiva participação dos interessados.

\subsubsection{Na Lei $n^{\circ}$ 10.257. de 2001 (Estatuto da Cidade)}

O Estatuto da Cidade, ou "Lei do Meio Ambiente Artificial" — segundo Celso Fiorillo $^{75}$ - regulamenta os arts. 182 e 183 da Constituição da República e, entre outras providências, estabelece as diretrizes gerais da política urbana, contendo "normas de ordem pública e interesse social que regulam o uso da propriedade

72 DI PIETRO, Maria Sylvia Zanella. Direito Administrativo, p. 518.

73 DI PIETRO. Maria Sylvia Zanella. Direito Administrativo, p. 518.

74 Direito Ambiental Brasileiro, p. 226.

75 Estatuto da Cidade Comentado, p. 15. 
urbana em prol do bem coletivo. da segurança e do bem-estar dos cidadãos, bem como do equilíbrio ambiental" (art. $1^{\circ}$, parágrafo único).

Contempla a realização de audiências públicas, expressamente, em três momentos:

No art. $2^{\circ}$, XIII. como uma das "diretrizes gerais" da política urbana. cujo objetivo é "ordenar o pleno desenvolvimento das funções sociais da cidade e da propriedade urbana", consta a realização de audiência pública com a "população interessada nos processos de implantação de empreendimentos ou atividades com efeitos potencialmente negativos sobre o meio ambiente natural ou construído, o conforto ou a segurança da população".

A política urbana, como ressalta Celso Fiorillo. "tem por objetivo, em apertada síntese, ordenar a cidade em proveito da dignidade da pessoa humana" 76 . e é nesse contexto que se insere a audiência pública.

Outra previsão consta do art. $40, \S 4^{\circ}$, I, dessa Lei ${ }^{\circ} 10.257 / 2001$, segundo o qual, para o processo de elaboração do plano diretor e a fiscalização de sua implementação, devem os Municípios promover "audiências públicas e debates com a participação da população e de associações representativas dos vários segmentos da comunidade".

O plano diretor, obrigatório para as cidades com mais de vinte mil habitantes, tem sede constitucional como elemento da política urbana e, segundo o art. 182, § $1^{\circ}$, da Constituição da República, "é o instrumento básico da política de desenvolvimento e de expansão urbana".

A audiência pública, outrossim, é um dos instrumentos para gestão democrática da cidade (art. 43, II, da Lei ${ }^{\circ} 10.257 / 2001$ ), e deve ser realizada pelos Municípios como condição obrigatória para aprovação pela Câmara Municipal, como via de participação direta dos particulares na gestão orçamentária, quando da preparação das propostas do plano plurianual, da lei de diretrizes orçamentárias e do orçamento anual (art. 44).

Isso atesta, "sob o ponto de vista jurídico, a vontade do legislador de submeter ao próprio povo - livre de 'intermediários' institucionais - a gestão democrática da cidade $" 77$.

\section{Considerações finais}

A realização de audiências públicas. como instrumento da participação popular na função administrativa. é inerente ao Estado Social e Democrático de Direito, servindo, também, para controle da atividade administrativa.

Essa participação popular tende a ser ampliada para "maior afirmação de um costume democrático" e para que a autoridade administrativa tenha condições de

76 Estatuto da Cidade..... p. 28.

77 FIORILlO, Celso. Estatuto da Cidade.... p. 84. 
melhor administrar. munida de opiniões mais próximas da realidade, trazidas pelos representantes dos interesses coletivos ${ }^{78}$.

"Sempre que direitos coletivos estiverem em jogo, haverá espaço para a realização de audiências públicas" ${ }^{79}$. Conseqüentemente, as previsões identificadas ao longo deste estudo não são exaustivas, mas simples exemplos da presença do particular na realização da função administrativa, "dentro de um objetivo maior de descentralizar as formas de atuação e de ampliar os instrumentos de controle" ${ }^{80}$.

Ao dirigir uma audiência pública o agente público deve zelar pelos seus princípios regedores, particularmente a oralidade e o debate ou efetiva participação dos presentes acerca da matéria relevante de interesse público que fundamentou a sua convocação.

A audiência pública, no Brasil, tem previsão na Lei $n^{\circ}$ 9.784/1999, como mecanismo de instrução do processo administrativo federal, visando ao desempenho da função administrativa pelos entes da Administração Pública Direta e Indireta. dos três Poderes da União. É contemplada, também, para exercício dessa função, em leis específicas que regem o meio ambiente, inclusive o artificial disciplinado no Estatuto da Cidade, as licitações e contratos administrativos, a concessão e permissão de serviços públicos, os serviços de telecomunicações e as agências reguladoras.

Representa a audiência pública, outrossim, indispensável instrumento para realização da missão institucional do Ministério Público, achando-se prevista, ainda, no processo legislativo e no processo judicial - aqui restrita ao processo de controle concentrado da constitucionalidade das normas.

Há de se ressalvar, no entanto, que os passos dados pelo legislador nacional no sentido de incrementar a participação popular na Administração Pública e demais setores do Estado, através, entre outras modalidades. da realização de audiência pública. não serão suficientes para consecução dos objetivos se for resolvida a questão política atinente ao "grau de desenvolvimento e efetivação da democracia" ${ }^{81}$, vez que os mecanismos jurídicos não bastam, por si só, para determinar a participação do povo - via de regra acomodado e desinteressado das questões sociais.

\section{Referências}

ANTUNES, Paulo de Bessa. Direito Ambiental. 3. ed., Rio de Janeiro: Lumen Juris, 1999.

ARGENTINA. Secretaría de Energía del Ministerio de Economia. Ente Nacional Regulador de la Eletricidad. Las audiencias públicas. Disponível na Internet em

78 RAMOS, Elival da Silva, citando Massimo SEVERO, in A valorização do processo administrativo..., p. 93.

79 OLIVEIRA. Gustavo Henrique Justino de. As audiências públicas e..., p. 161.

80 DI PIETRO. Maria Sylvia Zanella. Direito Administrativo. p. 518.

81 MODESTO. Paulo. Participaçāo Popular na Administraçāo Pública... p. 3. 
http://www.enre.gov.ar/web/web.nsf/Files/97.07.pdf\$FILE/97p07.pdf. Acessado em 09.07.2002.

BANDEIRA DE MELLO. Celso Antônio. Curso de Direito Administrativo, 12. ed.. São Paulo: Malheiros, 2000.

BASTOS. Celso Ribeiro e MARTINS, Ives Gandra da Silva. Comentários à Constituição do Brasil, São Paulo: Saraiva, 1995, 4. vol., tomo I.

BORGES, Alice Gonzalez. Processo Administrativo e Controle, Revista de Direito Administrativo, Rio de Janeiro: Renovar, vol. 226. p. 177-186. out/dez-2001.

BRASIL. Câmara dos Deputados. Regimento Interno da Câmara dos Deputados. Disponível na Internet em http://www.camara.gov.br/Internet/Regimento/RegInterno.pdf. Acessado em 09/7/2002.

BRASIL. Senado Federal. Regimento Interno do Senado Federal. Disponível na Internet em http://www.senado.gov.br/bdtextual/regSF/rsf93_77.htm\#E31E6. Acessado em 18.7.2002.

BRASIL. Ministério do Meio Ambiente. Conselho Nacional do Meio Ambiente. Resoluções CONAMA. Disponível na Internet em http://www.mma.gov.br/ port/conama/res. Acessado em 09.7.2002

BUENO. Vera Cristina Caspari Monteiro Scarpinella. As leis de procedimento administrativo. Uma leitura operacional do princípio constitucional da eficiência, Revista de Direito Constitucional e Internacional. São Paulo: RT, vol. 39, p. 267-288. abr/jun-2002.

BUENOS AIRES. Asociación de Abogados de Buenos Aires. Ley $n^{\circ} 6$ Audiencia Pública de la Ciudad de Buenos Aires Argentina. Disponível na Internet em http://www.aaba.org.ar/bi040006.htm. Acessado em 09.07.2002.

Gobierno de la Provincia. Reglamento de Audiencias Públicas. Disponível na Internet em http://www.gba.gov.ar/mosp/fiduciario/reglamento.htm. Acessado em 09.07.2002.

Legislatura. Constinución de la Ciudad Autônoma de Buenos Aires. Disponível na Internet em http://www. legislatura.gov.ar/llegisla/constcba/htm. Acessado em 09.07.2002.

CARVALHO FILHO, José dos Santos. Processo Administrativo Federal (Comentários à Lei $n^{\circ}$ 9.784 de 29.1.1999). Rio de Janeiro: Lumen Juris, 2001.

DI PIETRO. Maria Sylvia Zanella. Direito Administrativo, 14. ed.. São Paulo: Atlas, 2002.

Participação Popular na Administração Pública, Revista de Direito Administrativo, Rio de Janeiro: Renovar, n. 191. p. 26-39. jan-mar/1993.

FERRAZ. Sérgio e DALlARI. Adilson Abreu. Processo Administrativo, 1. ed., 2. tiragem. São Paulo: Malheiros, 2002.

FIORILlO. Celso Antonio Pacheco. Estatuto da Cidade Comentado, São Paulo: RT, 2002.

e RODRIGUES, Marcelo Abelha. Manual de Direito Ambiental e Legislação Aplicável, 2. ed.. São Paulo: Max Limonad, 1999.

GORDILLO. Agustín. Tratado de Derecho Administrativo. 4. ed., Buenos Aires: Fundación de Derecho Administrativo. 2000, Tomo 2. Disponível na Internet em http://www.gordillo.com/Pdf/2-4/2-4 ${ }^{a} x i . p d f$. Acessado em 09.07.2002. 
JUSTEN FILHO, Marçal. Comentários à Lei de Licitaçôes e Contratos Administrativos, 7. ed.. São Paulo: Dialética, 2000.

MACHADO, Paulo Affonso Leme. Direito Ambiental Brasileiro, 7. ed., 2. tiragem, São Paulo: Malheiros, 1999.

MARTINS, Ives Gandra da Silva e MENDES, Gilmar Ferreira. Controle Concentrado de Constitucionalidade - Comentários à Lei no 9.868, de 10.11.1999, São Paulo: Saraiva, 2001.

MAZZILLI, Hugo Nigro. O Inquérito Civil, São Paulo: Saraiva, 1999.

MEDAUAR, Odete. Direito Administrativo Moderno, 6. ed., São Paulo: RT, 2002. MELlO, Rafael Munhoz de. Processo Administrativo, Devido Processo Legal e a Lei $n^{\prime \prime}$ 9.784/99, Revista de Direito Administrativo, Rio de Janeiro: Renovar, vol. 227, p. 83-104, jan/mar-2002.

MILARÉ, Édis. Direito do Ambiente, São Paulo: RT, 2000.

MODESTO, Paulo. Participação Popular na Administração Pública. Mecanismos de Operacionalização. Disponível na Internet em http://wwwl l.jus.com.br/doutrina/texto.asp?id=2568, acessado em 20.06.2002.

MOREIRA NETO, Diogo Figueiredo. Direito da Participação Política. Legislativa - Administrativa - Judicial, Rio de Janeiro: Renovar, 1992.

OLIVEIRA, Gustavo Henrique de. As audiencias públicas e o processo administrativo brasileiro. Revista de Direito Administrativo, Rio de Janeiro: Renovar, vol. 209, p. 153-167, jul/set-1997.

PODER CIUDADANO. Manejando conflitos y mejorando la transparencia a través de la participación ciudadana: El caso del Puente La Serna en Argentina. Disponível na Internet em http://www.poderciudadano.org.ar/prog05E.htm. Acessado em 09.07.2002.

RAMOS, Elival da Silva. A valorizaçāo do processo administrativo. O poder regulamentar e a invalidação dos atos administrativos, As Leis de Processo Administrativo Lei Federal 9.784/99 e Lei Paulista 10.177/98, coordenação de Carlos Ari Sundfeld e Guillermo Andrés Muñoz, São Paulo: Malheiros, p. 75-93, 2000.

SOARES, Fabiana de Menezes. Direito Administrativo de Participação (Cidadania, Direito, Estado e Município), Belo Horizonte: Del Rey, 1997.

SUNDFELD, Carlos Ari. Processo e procedimento administrativo no Brasil, As Leis de Processo Administrativo Lei Federal 9.784/99 e Lei Paulista 10.177/98, coordenação de Carlos Ari Sundfeld e Guillermo Andrés Muñoz, São Paulo: Malheiros, p. 17-36, 2000. 


\section{O Estado na Preservação de Bens Culturais}

O Tombamento

Sonia Rabello de Castro

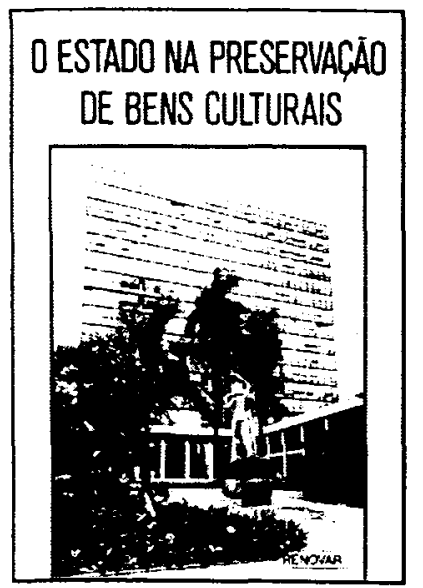

Esta obra trata do instituto jurídico do tombamento, explorando e reportando a experiência judicial brasileira na área, bem como analisando as formas e limites da atuação do Estado na preservação do nosso Patrimônio Cultural. Enfim, é uma visão crítica do instituto do tombamento a partir da própria lei, e de sua leitura pela doutrina e jurisprudência nacionais.

Ref. 0035

Form. 14x21
Brochura

1991
158 págs.

\section{O Jeito na Cultura Jurídica Brasileira}

Esta obra destaca as vertentes positivas e negativas do uso do "jeito" no Brasil nos tribumais, na administraçāo e na vida econômica e política do país em geral. Em alguns dos seus aspectos, reflete uma fase já ultrapassada da nossa história, na qual o país ainda era dominado pelo paternalismo e corrompido pela infração, mas, em outros, apresenta problemas ainda atuais e que necessitam de soluçào urgente.

Keith S. Rosenn

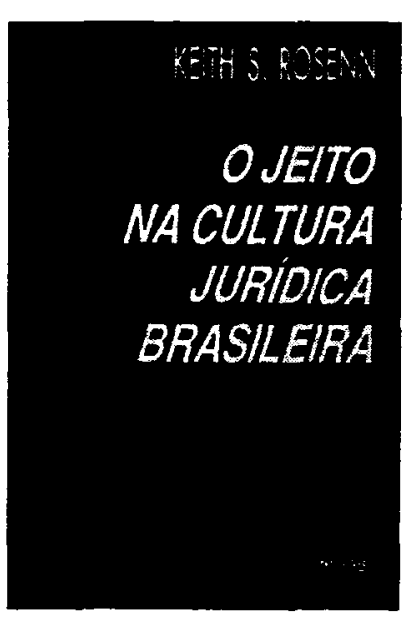

Ref. 0179

Brochura

Form. 14x21 1998

138 págs. 